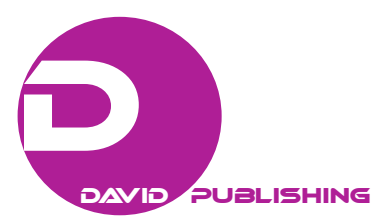

\title{
Thoughts on Stimulating the Employee’s Work Efficiency in State-Owned Enterprises
}

\author{
Yuan Gao \\ Petrochina Lanzhou Petrochemical Company, Lanzhou, China
}

\begin{abstract}
State-owned enterprises are the basic guarantee of China's economic and social development, the leading force in the field of strategic competition, but also the main provider of national social wealth accumulation. Although in many strategic areas, the operating efficiency of state-owned enterprises cannot be simply measured by the input profit margin; state-owned enterprises use state and social resources to operate. Shouldering the responsibility of preserving and increasing the value of state-owned assets also is the responsibility of all state-owned enterprise managers and employees. However, the management efficiency of state-owned enterprises is relatively low, and employees’ performance management and incentives have been lack of innovation and improvement. This paper analyzes the current state-owned enterprises in China, the characteristics of performance management, as well as the problems faced, and discusses the measures to encourage the efficiency of state-owned enterprises employees.
\end{abstract}

Keywords: state-owned enterprises, performance management, work efficiency, inspiration

\section{Introduction}

Since China implemented the reform and opening-up policy in 1978, state-owned enterprises play a cornerstone and mainstay in the development of our country. Relying on the establishment of a large number of state-owned enterprises, a relatively complete industrial system was established in the early days of the founding of the People's Republic of China, and transformed from a backward agricultural country to an industrial country. In the breakthrough of industrial and social modernization, state-owned enterprises also led to break the blockade of western countries. In the new era of the great rejuvenation of the Chinese nation, state-owned enterprises have to undertake a new historical mission to solve the contradictions of "imbalance" and "inadequacy". However, compared with the advanced representatives of private enterprises, the management efficiency of state-owned enterprises has been criticized by people, which is attributed to the serious principal-agent problem and the soft supervision caused by the close relationship with the government. However, these problems also exist in private enterprises, the principal-agent problem is the fundamental feature of modern enterprise system, and soft supervision in the financial operation of private enterprises also began to appear, so a simple corresponding relationship of these reasons and enterprise ownership do not exist. After years of deepening reform, China's state-owned enterprises have undergone fundamental changes in the property rights system, management system, and governance institutions; and the state-owned enterprises'

Yuan Gao, master, Petrochina Lanzhou Petrochemical Company, Lanzhou, China.

Correspondence concerning this article should be addressed to Yuan Gao, Petrochina Lanzhou Petrochemical Company, Lanzhou 730060, China. 
operating conditions have undergone major changes in 2017. There are also many improvements in the performance management and incentive of employees in state-owned enterprises, but how to stimulate the subjective initiative and creativity of employees, we need to analyze and explore the development trend of state-owned enterprises in the new era.

\section{The Current Situation and Development Trend of State-Owned Enterprises}

With the substantial progress made in the reform of state-owned enterprises in recent years, the dividends of reform began to appear. According to the data released by the Ministry of Finance, the total profit of state-owned enterprises in China reached nearly 2.9 trillion in 2017, an increase of 23.5\% year-on-year, making the largest increase since 2011. Traffic, petrochemical, coal, and other industries increased considerably, and nonferrous metals and iron and steel industries turned into profits. By the end of 2017, the total assets of non-financial state-owned enterprises had reached 83.5 trillion yuan, and the total assets of state-owned financial enterprises had reached 241 trillion yuan. The number of state-owned enterprises is small and the total assets account for less than a quarter of the total social assets, but the assets are concentrated and the large enterprises are in the majority. From the net assets of industrial enterprises above designated size, state-owned enterprises account for $40 \%$, while private enterprises only account for $24 \%$.

Among the top 500 enterprises in the world in 2018, 115 enterprises in the mainland of China were listed, of which 83 were state-owned enterprises. State-owned enterprises have made brilliant achievements in many high-tech and high-capital fields and have benefited the development of enterprises in various industries and the well-being of the whole society. For example, the digestion and breakthrough of high-speed rail technology have greatly improved the efficiency of transportation and the competitiveness of the industry in our country, invested heavily in building a 4G/5G network to open to the whole society; and the reduction of fees and the acceleration of the speed have promoted the development of the whole society and the prosperity of the network economy.

At present, the reforming line and specific measures of state-owned enterprises are clearer and the top-level design is constantly improving. On the one hand, the reform policy documents are systematized, including the guiding documents of strategic orientation, such as the Guiding Opinions of the CPC Central Committee and the State Council on Deepening the Reform of State-owned Enterprises, and the proposals for the implementation of specific areas, such as the Opinions of the State Council on Promoting the Reform of State-owned Capital Investment and Operating Companies; on the one hand, the implementation of reform measures has been accelerated. At present, the completion rate of the reform of the company system of the national inherent enterprises has exceeded $90 \%$. The reform of the mixed ownership system in the core areas of power, railway, civil aviation, military industry, and petroleum is also in the exploratory pilot stage.

The state-owned enterprises, especially the central enterprises, as the providers of basic products and services, the explorers, and leaders of industry and technology, are the main force to realize the transformation and upgrading of China's economy and society, and also the economic guarantee to adhere to the socialist system with Chinese characteristics. Therefore, China must always adhere to the strong state-owned enterprises, through continuous internal reform, and constantly improve business vitality, control, and influence and risk resistance. It can be foreseen that state-owned enterprises will invest more and develop more rapidly in strategic areas, such as aerospace, bio-hospital, supercomputer, marine technology, and so on, and deepen reform in more competitive areas, and constantly strengthen state-owned enterprises through more scientific 
management system innovation and more market-oriented enterprise management. Enterprise has global sustainable operation capability. As the core competitiveness of enterprises, how to enhance the enthusiasm, creativity, and efficiency of employees and constantly attract more and better talents is a problem that state-owned enterprises must consider and solve while reforming the management system and business model.

\section{The Characteristics and Problems of Performance Management in State-Owned Enterprises}

Performance management in modern enterprise management is an advanced tool of human resource management. It is through clear quantitative evaluation rules and standards, and constantly matches and optimizes the post responsibilities with the employee's ability, needs, and prospects, so as to stimulate the employee's maximum work efficiency, and feedback to match the remuneration and development opportunities. However, the use of performance management tools is not mechanized; we must rely on communication between people, from the qualitative and quantitative perspective of comprehensive evaluation, in order to be more close to the truth. Therefore, the use of performance management tools is affected by the enterprise property rights model, management system and managers' personal characteristics, and other factors. Compared with private enterprises, state-owned enterprises are subject to more restrictions and influencing factors in employee performance management, so there are more problems in this respect.

From the point of view of performance management, it has been generally believed that there is no concept of bankruptcy liquidation in state-owned enterprises, whether wholly state-owned or state-controlled enterprises, even if the enterprises continue to lose money, the final result is probably not bankruptcy settlement, but merger and reorganization. Therefore, whether managers at all levels or ordinary employees, state-owned enterprises from top to bottom diffuse this worry-free comfort. Managers do not pay enough attention to the efficiency of enterprise operation and team building, and they will not pay too much attention to the fairness and incentive of performance appraisal. In this way, apart from a few high-level sense of responsibility and the spirit of struggle, as well as forced to make a living of ordinary grassroots staff, a large number of people lack of enthusiasm and subjective initiative to work.

From the realistic basis of performance management, fuzzy management objectives, rigid personnel system, and incentive system "humanization" lead to the lack of independence of performance management. Only when the organizational objectives are clear, can it be decomposed into each team, each level of managers, and all ordinary employees. Every enterprise employee has a clear job responsibility, performance goals, output standards, and a clear commitment to return. Only in this way, can the role of performance management tools be brought into full play. However, the problems of vague or softening management objectives, bureaucratization of personnel system, and human disturbance in incentive system are common in state-owned enterprises, which result in the formality of performance management.

Affected by the above factors, although the reform of state-owned enterprises has been deepening in recent years, the deficiencies in performance management are still prominent. On the one hand, with the increasing demand for business efficiency, the employee performance calendar and incentive system have not been improved synchronously, resulting in the relative decline of employee income and welfare. On the other hand, compared with the booming private economy, the psychological gap of employees has increased, and the enthusiasm and creativity of employees have been further frustrated. On the one hand, the positive correlation between personnel changes and development path and job performance is still not obvious. Although the 
personnel system of state-owned enterprises is fairer and more just after the reform of the company system, its inherent gene determines the higher-level development, and the background, seniority, and relationship are more decisive. Especially in the bad economic environment, the survival of state-owned enterprises is more secure than that of ordinary private enterprises, at this time even the grass-roots positions are full of relationship and background competition.

In order to stimulate the enthusiasm and creativity of employees, we must thoroughly change the actual application of performance management in state-owned enterprises. At the present stage of deepening reform in state-owned enterprises, we need to change the management system and methods more boldly and thoroughly.

\section{Measures to Encourage the Efficiency of State-Owned Enterprises}

It is a matter of operational efficiency to stimulate the working efficiency and creativity of employees in an enterprise, but there is no conflict between ownership and property rights for the control of an enterprise. On the contrary, as long as the state-owned enterprises can be firmly controlled in the hands of property rights and ownership, the influence and dominance of state-owned enterprises in the industry or field can be promoted by stimulating the enthusiasm and creativity of employees and improving the operational efficiency of state-owned enterprises. Therefore, this paper argues that we should boldly implement the modern enterprise management system in the state-owned enterprises and improve the application of performance management tools from the following aspects:

\section{The "Hardening” of State-Owned Enterprises Budgetary and Objective Constraints}

Clear organizational objectives are the prerequisite for enterprises to carry out all their business and management activities. Just as the owners of private enterprises have clear objectives for their investment returns, state leading organs and economic management departments must clearly define the operational objectives of state-owned enterprises, including economic data indicators, technical realization, social responsibility, employment, team capabilities, and so on. The scale and plan endowed by resources should be strictly stipulated and monitored, especially the state-owned enterprises after the reform of mixed ownership. "Hardened" objectives and budget constraints can provide a reliable basis for performance management to decompose objectives, job descriptions, and personnel matching, and cannot lead to the formalization of performance management plans and measures due to policy changes or human factors in the implementation process.

\section{Clarify the Relationship Between Employee Development and Survival}

Under the premise that the state-owned enterprises will not be easily liquidated, it is necessary to separate the development of employees from the sticky relationship between the survival of enterprises, and make it clear that the hiring and turnover of employees are only related to personal performance, especially for senior managers, especially the intervention of administrative forces should be gradually stripped away. The large platform and stability of state-owned enterprises are two important factors to attract talents. However, due to unfair personnel system and performance management, many people are conscientious or talented, but there are no all the resources of the lower and middle-level employees, lack of space and channels for personal development, and on the contrary, they assume responsibilities and tasks beyond the return. Even in some scenarios, they will be "stolen" or "shared" fruits of labor. Therefore, only by linking the personal development of managers and employees with performance, contribution, and ability, and being fair and fair, can the enthusiasm and 
creativity of the whole staff be stimulated. Although in the short term, it will lead to internal contradictions due to the infringement of certain vested interests, only resolutely remove the "evil" can we achieve a new life.

\section{Accelerate the Exploration and Trial of Mixed Ownership in Key Areas}

For some competitive areas, the reform of the corporate system of state-owned enterprises is going faster. These state-owned enterprises will be able to meet the challenge of the full-scale market competition with a comprehensive and standardized modern enterprise management system in the near future. However, in the military industry, petroleum, railway, and other core basic areas, only through the reform of mixed ownership, the introduction of social cooperative capital, shareholding entities, and personnel, the use of the board of directors, shareholders' meeting, and other joint decision-making and supervision organizations, in the enterprise to continuously promote the optimization of management systems and methods, check and balance administrative power. The intervention will ultimately achieve a win-win situation of national interests and social interests. Specifically, we can bring in outstanding investors, enterprises, and entrepreneurs from all walks of life, bring into full play the integration of cross-industry, cross-market, and cross-technology, and learn from each other about strengths and weaknesses. For example, a number of outstanding private enterprises, such as Huawei, Alibaba, and Tencent can be state-owned in terms of products, technology, business model, and company management. The business development and organization management of enterprises are of great help.

\section{Share the Achievements of Enterprise Development With Employees}

From the perspective of individual needs, anyone can get the corresponding economic and spiritual returns while making efforts and contributions. The dividends released by the reform of state-owned enterprises must be shared with employees in a timely manner while returning to the state and society. Under the new management system, the employee's income, welfare, and development commitment should first be matched with the new goal requirements and performance requirements. The most realistic is that under the environment of rising prices and increasing pressure of urban life, the working enthusiasm and creativity of ordinary employees can be stimulated directly by raising income and welfare levels. Especially in the areas where many state-owned enterprises have the dominant power, a small amount of salary and welfare increases can significantly improve the attraction of talent.

\section{Strengthen the Basic Work of Performance Management}

When the reform of state-owned enterprises gradually gives a better implementation environment for performance management, the personnel team and managers at all levels of state-owned enterprises should quickly establish the ability to implement performance management tools. Firstly, the system of performance management system and toolkit is constructed, including clear performance goal setting and recording rules, decomposition operation rules of performance goals, organization and responsible person, function and goal description of organization and post, performance appraisal tool and communication mechanism, etc. Only when the systematic performance management system is established, and specific operational guidance and tools can be used, can performance management and incentive system be seen and felt, and employees will be more active to think, promote, and create.

\section{References}

Du, W. J. (2018). Research on employee relationship management mode under the diversified employment form of state-owned enterprises. Market Modernization, (12), 53-54. 
Fan, X. Y. (2017). Analysis on the current situation and measures of staff motivation in state-owned enterprises. Money China, (13), 128-129.

Yang, Y. (2018). Research on human resources performance improvement of state-owned enterprises based on catfish effect. China Journal of Commerce, (27), 187-188.

Zhang, L. (2018). Strategy Research on performance appraisal of state-owned enterprises in the new situation. Tax Paying, (25), $154,156$.

Zhang, L. F. (2017). Analysis and countermeasures of staff motivation mechanism in the reform of state-owned enterprises. Knowledge Economy, (5), 103, 105.

Zheng, S. Y. (2017). Countermeasures for training state-owned enterprises' human resources management under the new situation. Human Resource Development, (4), 95-96. 